\title{
The impact of grassland management on biogeochemical cycles involving carbon, nitrogen and phosphorus
}

\author{
C. Rumpel ${ }^{1,2^{*}}$, A. Crème ${ }^{2}$, P.T. $\mathrm{Ngo}^{3}$, G. Velásquez ${ }^{3}$, M.L. Mora ${ }^{3}$, A. Chabbi ${ }^{2,4}$ \\ ${ }^{I}$ CNRS, IEES (UMR UPMC-CNRS-UPEC-INRA-IRD), Campus AgroParisTech, Thiverval-Grignon, France \\ ${ }^{2} I N R A, \quad U R$ Ecosys (UMR INRA-AgroParisTech), Campus AgroParisTech, Thiverval-Grignon, France \\ ${ }^{3}$ Universidad de La Frontera Scientific and Technological Bioresource Nucleus (BIOREN-UFRO), \\ Temuco, Chile ${ }^{4} I N R A, U R$ 3PF, Lusignan, France *Corresponding author: cornelia.rumpel@grignon.inra.fr
}

\begin{abstract}
Grassland introduction into intensively managed agricultural landscapes may enhance soil organic matter (SOM) content and ecosystem services. However, the magnitude of this effect depends on grassland management practices, and their influence on the soil system. The aim of this paper is to highlight these impacts and their consequences for SOM dynamics and element cycling. We focused in particular on the effect of different grassland management practices in terms of grazing regime, fertilization, and species choice.

While carbon, nitrogen and phosphorus cycles are more strongly coupled under grassland as compared to permanent cropping, uncoupling of elemental cycles may occur through management intensification. Grazing regime, fertilization and species choice affect elemental coupling and SOM turnover via organic matter input and rhizosphere activity to different extent, thereby resulting in contrasting SOM storage. Grazing may be more beneficial for SOM contents compared to mowing up to a certain animal density depending on soil type and pedoclimatic context. SOM storage may be increased in some cases through specific fertilizer additions, whereas in others no change was observed. Species choice, e.g. high diversity or introduction of legumes, influence element budgets and soil nutrient availability through plant physiological constraints as well as intraor interspecific interactions. The effect of different plant species mixtures on soil parameters has rarely been elucidated.

We conclude that the impact of grassland management practices on SOM of different soil types and the resulting ecosystem services, such as $\mathrm{C}$ and nutrient storage need further research in contrasting pedoclimatic contexts. More studies on the controls of belowground biogeochemical cycling of elements are necessary in order to fully understand and manage belowground processes via aboveground plant communities.
\end{abstract}

Keywords: Grassland management, elemental coupling, carbon, nitrogen, phosphorus, soil organic matter 


\section{Introduction}

By now it has become evident that intensive agriculture leads to organic matter depletion of soils (Lal, 2004), threatening the ability of agroecosystems to provide ecosystem services. Replenishing soil organic matter (SOM) pools may be possible through the adaptation of land use practices, which favor permanent soil cover and high carbon (C) input belowground (Whitmore et al., 2014). One option may be the establishment of grasslands into agricultural landscapes (Franzluebbers, 2012). Grassland systems include rangelands, shrublands, pastureland, and cropland sown with pasture and fodder crops. They are important in many parts of the world, contain about $20 \%$ of the world C stocks (FAOSTAT, 2009; Ramankutty et al., 2008), and have multiple functions and values in terms of ecosystem services (Conant et al., 2010). Grasslands may reduce soil erosion through a permanent soil cover and dense rooting systems, thus favoring soil fertility, water quality and water retention, compared with other crops (Conant et al., 2010). The high organic matter $(\mathrm{OM})$ content of grassland soil is beneficial to soil quality due to its positive effects on aggregation, microbial activity and diversity as well as nutrient and water availability (Kononova, 1966; Allison, 1973; Tate, 1987).

One of the most important characteristics of the SOM pool is its response towards human interventions. In grassland systems, elemental cycles are strongly coupled (Soussana and Lemaire, 2014). However, intensive grassland management may lead to uncoupling of these cycles, leading to negative environmental impacts in terms of air and water quality (Dungait et al., 2012). Grassland management is therefore most important in determining if this land use system preserves its beneficial effects in terms of closed elemental cycles. As in grasslands, the main SOM stocks are found belowground, it is crucial to understand the effect of management strategies on the coupling via plant litter input and rhizosphere processes. Grassland management concerns species choice as well as management options, such as production versus pasture, grazing type and/or intensity and type of fertilisation, which may influence OM input as well as its dynamics. In recent years it has become evident that maintenance and increase of SOM may be closely related to microbial $\mathrm{C}$ use efficiency (Cotrufo et al., 2013) as well as the built up of microbial biomass (Miltner et al., 2012). Recent studies indicated that microbial growth stimulated by plant input of low molecular weight dissolved organic compounds may contribute to SOM built up (Bradford et al., 2013). It has been shown that microorganisms may be able to produce recalcitrant OM (Jiao et al., 2010) and even easily decomposable microbial products may be subject of stabilisation by interaction with the mineral phase (Rumpel et al., 2015). However, microbial turnover and subsequent SOM stabilisation by mineral interactions may have stoichiometric constraints requiring narrow $\mathrm{C}: \mathrm{N}: \mathrm{P}$ ratios (Kirkby et al., 2014), which associates a nutrient cost to soil $\mathrm{C}$ sequestration (Richardson et al, 2014). In addition to requiring nutrients, microbial built up of SOM may be counterbalanced or accentuated by priming effects, which are important processes in the plants rhizosphere (Merino et al., this issue). Positive priming refers to mineralisation of otherwise stable $\mathrm{C}$ through shifts in microbial community composition (Fontaine et al., 2003). However, in some cases the addition of organic matter to soil as well as rhizosphere processes may lead to a switch of the microbial communities with regards to the substrate they use preferentially, thereby protecting SOM from its decomposition (Kuzyakov and Gavrichkova, 2010). Plant communities are main controlling factors of these processes because they can 
alter the quality of their litter input as well as their rhizosphere processes. By such alterations, they influence soil microbial activity, water and labile $\mathrm{C}$ availability as well as $\mathrm{pH}$ and nutrient cycling (Peres et al., 2013; Frinzi et al., 2015). In this review, we support the hypothesis that for evaluation of $\mathrm{C}$ storage and nutrient availability in grassland soils, knowledge about the impact of management practices such as cutting or grazing, fertilisation and species choice on belowground processes is crucial (Figure 1). We aim to review the recent literature on different grassland management practices and their impact on the forms and turnover of carbon and major nutrients $(\mathrm{N}, \mathrm{P})$.

\section{Soil type and climate}

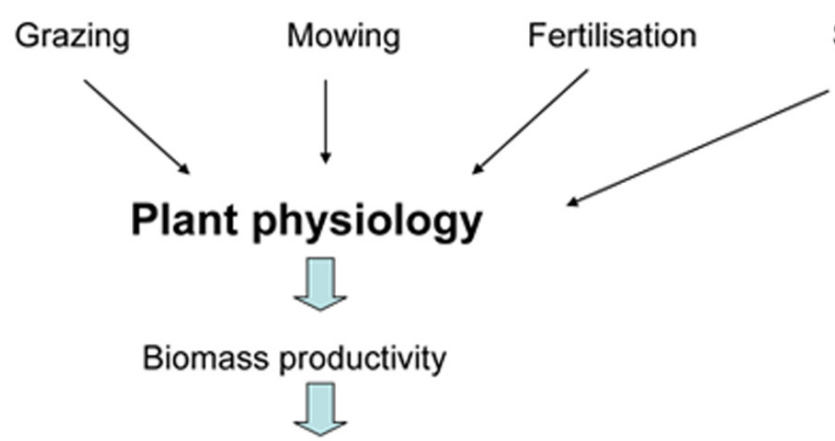

Litter deposition and root exudation

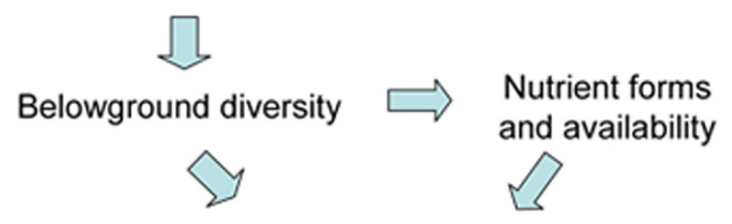

Soil organic matter storage

Figure 1. Grassland management effects on plant communities and potential impacts

\section{Element coupling and organic matter dynamics in grassland soil}

The amount of SOM stored in a given soil is determined by the balance of $\mathrm{C}, \mathrm{N}$ and $\mathrm{P}$ entering the soil, via plant production, atmospheric deposition or fertilisation, and $\mathrm{C}, \mathrm{N}$ and $\mathrm{P}$ leaving the soil driven by microbial processes through mineralization and leaching as $\mathrm{CO}_{2}, \mathrm{NH}_{4}, \mathrm{NO}_{3}$,
$\mathrm{PO}_{4}$ (Figure 2) as well as biomass export and erosion. Consequently, a main control on SOM storage is the $\mathrm{PO}_{4}$ (Figure 2) as well as biomass export and erosion. Consequently, a main control on SOM storage is the amount and type of residues that are produced by plants as the primary producers in the ecosystem and the amount and type of nutrient input. In natural grassland systems, the nutrient elements $\mathrm{N}$ and $\mathrm{P}$ are coupled closely with 
the $\mathrm{C}$ cycle through plant production via $\mathrm{CO}_{2}$ and $\mathrm{N}$ and $\mathrm{P}$ assimilation leading to plant growth (Figure 2). After the senescence process, when plants recovered some essential nutrients, in natural systems, litter is returned to soil and microbial decomposition starts and decoupling of elemental cycles occurs through mineralisation. However, new coupling of $\mathrm{C}, \mathrm{N}$ and $\mathrm{P}$ cycles also occurs through growth of the soil microbial biomass (Figure 2). These processes are extremely important, as they release nutrients for plant and microbial utilisation and also contribute to the accumulation of stabilized SOM (Miltner et al., 2012). In general, $\mathrm{C}$ and $\mathrm{N}$ are more strongly than $\mathrm{C}$ and $\mathrm{P}$, due the greater limitations of plant and microbial growth by $\mathrm{N}$ than $\mathrm{P}$ and the increasing decoupling of $\mathrm{P}$ from $\mathrm{N}$ and $\mathrm{C}$ during SOM formation (Dungaith et al., 2012). This may be due to strong sorption and thus immobilization of organic and inorganic $\mathrm{P}$ forms to soil minerals (Cerli et al., 2003). Because of its strong association with soil particles, soil erosion is one of the most important processes leading to P loss. As erosion under grassland is low due to permanent soil cover, little $\mathrm{P}$ loss may occur in these systems through this process (McLauchlan, 2006), while harvesting export may lead to $\mathrm{P}$ depletion in the long-term in unfertilised grassland soils (Pätzhold et al., 2013).

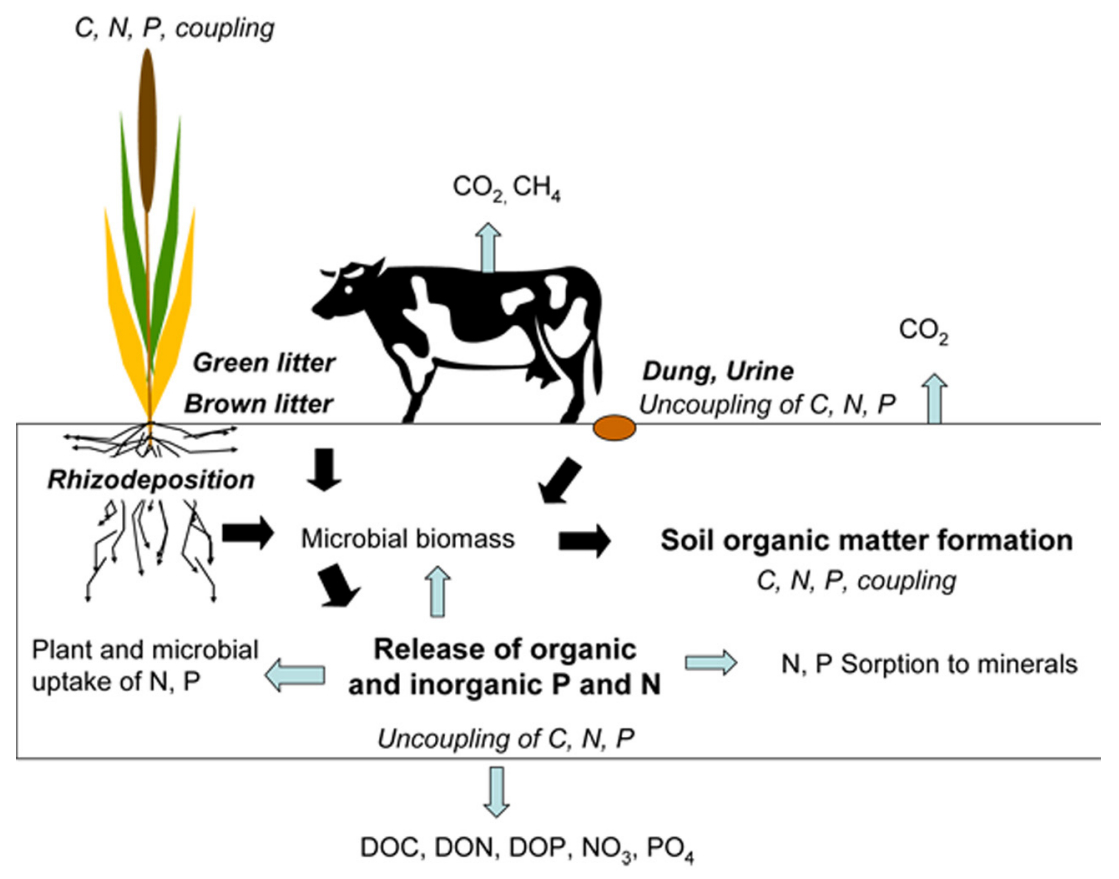

Figure 2. Processes leading to coupling and uncoupling of $\mathrm{C}, \mathrm{N}$ and $\mathrm{P}$ cycles in grassland soil (Soussana and Lemaire, 2014; Miltner et al., 2012; Sanaullah et al., 2010; Dungait et al., 2012; Parsons et al., 2012) 
In contrast, $\mathrm{N}$ is mobile in soil and subject to leaching losses mainly in form of nitrate if not taken up by plants and gaseous losses through denitrification and ammonia volatilization. In general nitrate leaching under grassland is greatly reduced as compared to cropland and recently it has been shown that grassland introduction into the cropping cycle reduces the amount of nitrate leached from the system (Robinson Kunrath et al., 2015). However, increasingly intensive grassland management also leads to high amounts of reactive $\mathrm{N}$ and $\mathrm{P}$ present in soil, which may in some cases be released from the system through leaching and volatilisation and contribute to its negative environmental impacts (Sharpley et al., 1994; Soussana and Lemaire, 2014). Traditionally, it has been supposed that organic $\mathrm{N}$ and $\mathrm{P}$ have to be mineralised before plant uptake. In recent years it has been shown that amino acids undergo rapid mineralisation (Farrell et al., 2011) as well as direct plant uptake (Hill et al., 2011) in grassland soil. The turnover rates of low molecular weight organic $\mathrm{N}$ in grassland soils was found to be rapid, suggesting that these compounds are very import for microbial and potentially plant nutrition despite their low quantitative amounts in soil solution (Wilkinson et al., 2014). Dissolved organic $\mathrm{P}$ also contributes in high proportion to total dissolved $\mathrm{P}$ losses under grassland soil especially when soils are rich in P (McDowell and Koopmens, 2006) or when they are subjected to dung input (Fuentes et al., 2012). These compounds are easily available to the soil microbial biomass (Turner et al., 2002) even after sorption to the mineral phase (Franson and Jones, 2007), but may also constitute a high proportion of $P$ leached from intensively used pasture systems (McDowell and Koopmans, 2006). It is unknown, whether dissolved organic P can be taken up by plant directly from the solution. The fate of low molecular weight organic compounds containing $\mathrm{P}$ and $\mathrm{N}$ in soil is insufficiently understood (Figure 3). Studies addressing C, $\mathrm{N}$ and $\mathrm{P}$ coupling should therefore also concentrate on dissolved organic compounds, which are a highly dynamic compartment in grassland soils constituting a link between soil, plants and microbes.

\section{Effect of grassland management on OM input}

Grassland management can impact coupling and decoupling of elemental cycles through regulation of plant production via fertilisation and the grazing regime. Stoichiometry of plant residues determines the intensity of microbial decomposition, and ultimately $\mathrm{C}$ sequestration. Under extensive management, for example, plant $\mathrm{N}$ nutrition status is low leading to longer residence times of plant litter, compared to intensive management where plants have higher $\mathrm{N}$ nutrition status (Klumpp et al., 2007). Thus in extensivly managed systems the resulting SOM may constituted mainly of labile particulate organic matter protected within soil aggregates and not through strong organomineral associations it may therefore be vulnerable to loss upon disturbance (Six et al., 2004). OM input into grassland soil occurs in the form of above- and belowground plant tissue (Figure 2). Aboveground litter input may occur as brown senescent litter in grazed pastures (Mazzinti et al., 1994). Under mowing regime, a significant proportion of aboveground plant litter is returned as fresh litter during harvest. It has been shown, that leaf litter of grassland species may be of very different quality depending whether or not it has been affected by the senescence process (Sanaullah et al., 2010). The initial litter quality determines its degradation behaviour in soil. This is true for aboveground as well as belowground litter additions (Redin et al., 2014). Total soluble sugar content is an important controlling factor in the earlier phase of decomposition, whereas the later stages of decomposition may be regulated by the lignin/ $\mathrm{N}$ ratio of initial litter. It was shown that grass litter added to soil at different stages of maturity decomposes at different rates and maintains theses differences for several years (Sanaullah et al., 2010). 
In temperate grassland systems, more than $80 \%$ of the net primary production is diverted to root production (Swift et al., 1979). Herbaceous species are less deep rooting than forest vegetation or shrubs and globally ca. $40 \%$ of all SOC in the first meter of grassland soil is found in the uppermost $20 \mathrm{~cm}$ (Jobbagy and Jackson, 2000). Root carbon input into soil may occur as root cell sloughing, other root debris, mucilage and root exudation. All may contribute greatly to SOM due to preferential stabilisation within the mineral matrix (Rasse et al., 2005), in addition to the root chemical composition, which makes root material more difficult to decompose compared to aboveground material (Bertrand et al., 2006). Rhizosphere processes, such as root turnover, rhizodeposition, root respiration and microbial response are extremely important in grassland soil. These processes may lead to stabilisation as well as destabilisation of soil carbon and nitrogen (Cheng and Kuzyakov, 2005). Plant roots may affect SOM decomposition through (1) decreasing mineral nutrient availability to soil microorganisms due to plant uptake (Schimel et al., 1989), (2) changing the physical environment in the rhizosphere (Shields and Paul, 1973), (3) increasing organic substrate supply and (4) enhancing microbial turnover due to fungal grazing. However, interactions at the rhizosphere level between soil microorganisms and roots of different plant communities are complex and remain poorly understood (Cheng and Kuzyakov, 2005). Rooting behaviour of plants and rhizosphere processes may be strongly influenced by grassland management, which can therefore impact the storage and composition of $\mathrm{C}, \mathrm{N}$ and $\mathrm{P}$ in soil. For example, defoliation of plants by grazing and cutting stimulates root exudation, thereby increasing the quantity of rhizomicrobial communities and their activities (Paterson and Sim, 1999; Hamilton et al., 2008), leading to increased availability of $\mathrm{P}$ and $\mathrm{N}$ through positive feedback mechanisms (Hamilton and Frank, 2001).
However, this effect may be transient and last only for some days (Henry et al., 2008; McDonald et al., 2004). Defoliation may also affect $\mathrm{C}$ flow and allocation within grasses (Kuzyakov et al., 2002) as well as N fixation and allocation in legumes (Dahlin and Martensson, 2008). However, these effects have been studied up to now mainly in pot experiments, whereas their assessment under natural conditions is scarce. Defoliation under natural conditions has been assessed by isotopic labelling of defoliated grasses. It has been shown that defoliation under field conditions alters belowground C allocation (Holland et al., 1996) and stimulates rhizospheric $\mathrm{N}$ mineralisation, which ultimately benefits the defoliated plants (Hamilton et al., 2008). It is not known, whether defoliation by grazing induces different physiological plant responses compared to cutting. In addition to above- and belowground litter, dung can constitute an important OM source in grasslands managed by grazing (Jarvis et al., 1996). On a pasture with a grazing intensity of 700 cow days $\mathrm{ha}^{-1} \mathrm{a}^{-1}$, an average of $6.4 \%$ of the grazed area is commonly covered by dung patches which provide a $\mathrm{C}$ input equivalent to 22.5 t C ha $^{-1}$ (Bol et al., 2000). By grazing and depositing dung and urine, large herbivores remove carbon and nutrients and return them by excretion, leading to cycling and redistribution, which in turn influences the structure and functioning of grassland systems (Heynes and Williams, 1993) as well as OM dynamics through carbon dioxide release and $\mathrm{OM}$ incorporation into soil. Dung is a source of labile C, N and P, which may increase microbial biomass (Lovell and Jarvis, 1996; Hatch et al., 2000) and induce priming of native organic matter (Fontaine et al., 2003). Molecular studies have shown that carbohydrates constitute part of the dung-derived C in soil (Dungait et al., 2009). While dung and urine deposition occurs in well defined patches, limited information is available about the impact of this labile $\mathrm{C}$ on the soil biogeochemical cycles at larger scales. 
Many types of grassland worldwide are managed by regular burning. Fire disrupts $\mathrm{C}, \mathrm{N}$ and $\mathrm{P}$ cycles by releasing much $\mathrm{C}$ and $\mathrm{N}$ in gaseous form and $\mathrm{P}$ in mineral form. In the long-term burning tends to conserve soil $\mathrm{P}$ while it removes $\mathrm{C}$ and $\mathrm{N}$ (Johnston et al., 2003). In addition fire-derived organic matter forms are deposited on soil. Quantification of this material in the major grassland ecosystems of the world showed a contribution between 5 and $30 \%$ of total SOM (Rodionov et al., 2010). This is high compared to agricultural soils, which do not accumulate firederived SOM even when subject to annual stubble burning (Rumpel, 2008). Fire-derived SOM forms are in general more difficult to degrade than plant-derived SOM due to their aromatic structure and low nitrogen content (Knicker, 2011). During fire, P is generally converted to inorganic forms, while $\mathrm{N}$ may be part of pyrogenic organic matter. However, the degradability of fire-derived SOM may vary according to fire conditions and chemical composition of the affected vegetation (Alexis et al., 2010). Moreover, fire-derived SOM forms may influence element cycles in grassland soil through their specific nutrient adsorption and plant growth stimulating properties (Criscuoli et al., 2014).

\section{Impact of harvesting regime and fertilisation on soil properties and processes affecting SOM stor- age and nutrient forms}

The SOM storage and stabilisation pathways may be influenced by grazing management of grassland ecosystems through alterations of OM input (see above) and associated soil properties. Intensive grazing leads to significantly decreased SOC stocks associated with higher bulk density in topsoils (Steffens et al., 2008, 2009) and additionally to lower mean-weight diameter of water stable aggregates, lower monosaccharide contents and lower contribution of microbial-derived sugars (Dormaar and Williams, 1998). The grazing regime (high or low intensity) greatly influences SOM dynamic (Steffens et al., 2009). Intensively grazed grasslands are dominated by fast-growing species producing litter low in lignin and rich in N, which is rapidly decomposed by bacteria (Bargett et al., 1998), whereas grasslands adapted to low grazing levels are dominated by slow growing species and slow litter decomposition (Michunas and Lauenroth, 1993). The two different plant communities have been reported to control SOM stocks through plant roots and their activity (Klumpp et al., 2009). Changes in C dynamics after grazing cessation may be slow (Klumpp et al., 2009) and not lead to $C$ sequestration in soils, where the mineral particles are already saturated with $\mathrm{OM}$ (Steffens et al., 2009). In contrast, light or moderate grazing does not necessarily decrease SOM contents (Cui et al., 2005). Grassland management by mowing may reduce $\mathrm{C}$ turnover as compared to grazing (Herold et al., 2014). It was found, that long-term grazing with cattle was more favourable for macroaggregation and aggregate stability and thus carbon storage than harvest by mowing (Franzluebbers et al., 2000). This corresponds to the increase of net $\mathrm{C}$ storage measured by $\mathrm{CO}_{2}$ fluxes in temperate grazing systems compared to mowed grasslands (Senapati et al., 2014). The higher $\mathrm{C}$ storage was attributed to greater export by harvest under cutting regime, whereas under grazing a substantial amount of $\mathrm{C}$ is returned in form of dung and urine (Senapati et al., 2014). However, grazing and mowing may also stimulate differently plant physiology and rhizospheric $\mathrm{C}$ input, thereby probably altering SOM storage in soil.

In terms of macronutrients, grasslands were found to favour the accumulation of organic $\mathrm{P}$ forms, which may be relatively available as compared to insoluble inorganic $\mathrm{P}$ forms, which accumulate during cultivation (Sharpley and Smith, 1985, Crew and Brooks, 2014). 
Grazing as well as cutting seems to remove P from grassland soils (Lilienfein et al., 2000; Pätzold et al., 2013). Although there are few studies on $P$ forms under different grazing regimes, a return of higher amounts of inorganic P compared to the ingested vegetation was found, suggesting transformation of organic forms in inorganic ones during the transit in the digestive tube (McDowell and Stewart, 2005). While P present in dung was found to parallel P concentrations in feed (McDowell et al., 2008), grazing animals lead to substantial uncoupling of $\mathrm{C}$ from $\mathrm{N}$ and P (Soussana and Lemaire, 2014). The majority of $\mathrm{P}$ and $\mathrm{N}$ are returned to the soil by urine or dung deposition, whereas about $70 \%$ of the ingested $\mathrm{C}$ is emitted as CO2 by respiration (Parson et al., 2013). Intensive dairy farming may however also increase $\mathrm{P}$ loss in dissolved organic form (Javie et al., 2010). $\mathrm{N}$ export from the site is usually complete in mowing systems and higher in dairy pastures compared to dry livestock ones (Parson et al., 2013). The return of $\mathrm{N}$ and $\mathrm{P}$ with animal excrements by manure occurs generally in labile form, which is much more mobile compared to initial feed (see above), and increases the $\mathrm{N}$ and $\mathrm{P}$ leaching losses if applied without prior treatment (Jouquet et al., 2011).

Apart from presence and absence of grazing animals, management of grassland may include the application of fertilisers (Figure 1; Table 1). Fertilisation is usually applied to counteract nutrient export and to maintain or intensify forage production. Many soils have been over fertilised in the past and therefore are high in organic matter leading to oversupply and subsequent nutrient loss from soil after grazing cession (McGovern et al., 2014). Recently it has been shown that loss of reactive P form high P soils may be reduced by manipulation of $\mathrm{N}$ fertilizer regime in order to stimulate $\mathrm{P}$ uptake through increased plant growth (Dodd et al., 2014).
Due to its effect on plant production, fertilisation may impact SOM storage. However, this effect is not entirely clear. While Ammann et al. (2007) concluded that conversion of arable land to grassland leads to a positive carbon balance only if the system receives extra nitrogen inputs, no relationship between the intensity of management and SOC stocks was found for Alpine grasslands (Zeller et al., 1997; Bitterlich et al., 1999). A review of global data sets revealed fertilised grasslands had, on average, higher SOC stocks than natural or less intensively managed systems (Conant et al., 2001). While the use of $\mathrm{N}$ fertilisers in most managed grassland systems seems absolutely necessary to maintain grassland productivity, soil P stocks of most temperate agricultural soils seem to be sufficient. Accordingly, Nyborg et al. (1997) found with increasing level of $\mathrm{N}$ fertilisation larger SOC contents associated with higher productivity for Canadian grasslands, while no change of SOM stocks was noted with increasing $\mathrm{P}$ fertiliser rates despite higher aboveground production for pastures in New Zealand (Schipper et al., 2012). In some cases, $\mathrm{N}$ and $\mathrm{P}$ fertilisation may even lead to decrease of SOM stocks by increasing microbial activity and altering $\mathrm{C}$ substrate utilisation pattern of soil microbial communities through changes of plant biomass composition (Li et al., 2014). These examples may illustrate that management effects on SOM are diverse and strongly dependent on pedoclimatic parameters (Mcsherry and Richie, 2013). (Table 1).

The mechanisms and in particular soil type effects, which lead to these contrasting results yet need to be elucidated. Moreover, the effects of different grassland management practices were assessed up to now mostly for topsoil horizons, although perennial species may affect a much larger volume of soil and greater soil depth than annual species (Beniston et al., 2014). 
Table 1. Contrasting effect of different management practices on element cycles and SOM storage

\begin{tabular}{|c|c|c|}
\hline $\begin{array}{l}\text { Management } \\
\text { practice }\end{array}$ & Effect on soil and nutrient forms & Reference \\
\hline \multirow[t]{2}{*}{ Mowing } & $\mathrm{C}$ and nutrient export with harvest & Parson et al., (2013) \\
\hline & $\begin{array}{l}\text { Reduced turnover of mineral } \\
\text { associated OC }\end{array}$ & Herold et al. (2014) \\
\hline \multirow[t]{5}{*}{ Grazing } & Decoupling of $\mathrm{N}, \mathrm{P}, \mathrm{C}$ cycles with & Parson et al. (2013) \\
\hline & reduction of C longevity & Soussana et al., (2014) \\
\hline & Decrease of SOM storage & Steffens et al. (2008, 2009 \\
\hline & $\begin{array}{l}\text { Stimulation of belowground } \\
\text { activity }\end{array}$ & Hamilton et al. (2008) \\
\hline & Increase of C flux below ground & Holland et al. (1996) \\
\hline \multirow[t]{3}{*}{ Fertilisation } & Increase of SOM storage & Conant et al. (2001) \\
\hline & No change in SOM storage & Schippers et al. (2012) \\
\hline & Decrease of SOM storage & Li et al. (2014) \\
\hline \multirow[t]{2}{*}{ Species diversity } & Increasing aggregate stability & Peres et al. (2013) \\
\hline & $\begin{array}{l}\text { Changes of nutrient aquisition } \\
\text { efficiency }\end{array}$ & Oelmann et al. (2011) \\
\hline \multirow{9}{*}{$\begin{array}{l}\text { Legume } \\
\text { introduction }\end{array}$} & Decrease of aggregate stability & Peres et al. (2013) \\
\hline & Increase of aggregate stability & Angers et al. (1999) \\
\hline & Higher contribution of organic $\mathrm{P}$ & Crème et al. submitted \\
\hline & Higher soil $\mathrm{N}$ and $\mathrm{C}$ & Fustec et al. (2010), \\
\hline & & Paustrian et al. (1990) \\
\hline & & Agbenin and Adeniyi (2005) \\
\hline & No change in soil $\mathrm{C}$ and $\mathrm{N}$ & Bell et al. (2012) \\
\hline & & Crème et al. submitted \\
\hline & Increased resistance to water stress & Sanaullah et al. (2012) \\
\hline
\end{tabular}




\section{Plant species and their impact on SOM and forms of macronutrients}

The formation of SOM and the forms of macronutrients in soil may be influenced by species composition of grasslands. In natural grasslands, species diversity is large compared to sown ones, which are rarely composed of more than three species. Introduction of animals tends to reduce this diversity due to selective grazing and varying stress resistance of different grassland species (Bargett et al., 1998). Diverse species rich grasslands are known to be characterised often by higher amounts of aboveground biomass than those consisting of few species (Hooper et al., 2005). They also penetrate larger volumes of soil due to diverse and complementary root traits (Körner and Spehn, 2002). Due to increased root activity and in turn higher soil organic carbon and soil microbial biomass concentrations, aggregate stability was found to be increased in soil under grasslands with high species diversity. (Peres et al., 2013). However, plant species diversity was also shown to decrease soil concentrations of plant available $\mathrm{N}$ due to complementary uptake (Niklaus et al., 2001). This is in contrast to plant available $P$, which was found to be unchanged in soil solution under more diverse grasslands (Oelmann et al., 2011). Diverse grasslands, seem to develop highly efficient $\mathrm{P}$ exploitation strategies, thereby being better prepared to respond to $\mathrm{P}$ limitations (Oelmann et al., 2011). The introduction of forage legumes, able to fix atmospheric nitrogen through symbiosis with Rhizobium into grasslands generally has a favourable impact on soil due to their deep rooting system and easy decomposable organic residues rich in nitrogen, which promote the development of micro-fauna and soil microflora. The direct availability of the fixed $\mathrm{N}$ to the roots minimizes nitrogen losses (Crews and Peoples 2005) and reduces the risk of $\mathrm{NO}_{3}$ leaching, acidification of soil, ammonia volatilization (Crews and Peoples 2004) and $\mathrm{N}_{2} \mathrm{O}$ emissions by denitrification (IPCC 2013). The introduction of legumes in pasture systems can increase the soil $\mathrm{N}$ content and cycling efficiency through legume residue deposition and root exudation (Fustec et al., 2010; Rasmussen et al., 2012; Schipanski and Drinkwater 2012). Symbiotic nitrogen fixation is the key process in $\mathrm{N}$ and $\mathrm{C}$ dynamics in agricultural systems containing legume species. It couples soil nitrogen and carbon cycles. In roots nodules of legume species, $\mathrm{N}_{2}$ fixing bacteria benefit from carbon inputs provided by the plant and make nitrogen available to the plant in mineral form. They reduce the atmospheric $\mathrm{N}_{2}$ in $\mathrm{NH}_{3}$ then $\mathrm{NH}_{4}$, using energy from the oxidation of carbohydrates (Butterbach-Bahl et al., 2011). The nodule metabolism depends on carbohydrate products fixed by photosynthesis in shoots and transported to the roots. The principal compound is sucrose. Each day, the nodule metabolism uses $40-50 \%$ of all photosynthetic products and $50 \%$ of this is returned to the atmosphere as $\mathrm{CO}_{2}$ by respiration (Gordon 1992). Legumes require more $\mathrm{P}$ than grasses. The high-energy cost of $\mathrm{N}_{2}$ fixation requires adenosine tri-phosphate (ATP) and therefore $\mathrm{P}$ to build and maintain functioning nodules. As a consequence, legume plants show higher concentration of $\mathrm{P}$ compared to other plants (Tsvetkova and Georgiev, 2007) and in soil under legume, organic forms of $\mathrm{P}$ tend to be present in higher concentrations compared to soil under grass species (Daroub et al., 2001 ; Crème et al., submitted).

The transfer of $\mathrm{N}$ and $\mathrm{P}$ from the legumes to the soil occurs by returning shoot and root litter after plant death as well as root exudates during the plant life. In the case of mowed grassland, only rhizodeposition will lead to enrichment of soil organic matter due to removal of the aboveground biomass. However, even in mowed grassland part of the biomass is lost during harvesting and readily decomposable (Sanaullah 
et al., 2010). In Lucerne grasslands, $3 \%$ to $4,5 \%$ of the fixed $\mathrm{N}$ is released as soluble compounds. However, roots and senescent nodules appear to be the main source of nitrogen in legume grasslands, especially as rhizodeposition increases with the age of the plants (Fustec et al., 2010).

When combining grasses with legume species in grassland systems, $\mathrm{N}$ fixation is more efficient with $9 \%$ to $18 \%$ more $\mathrm{N}$ fixed than in legume monocultures (Nyfeler et al., 2011; Schipanski and Drinkwater 2012) leading to higher the forage yields (Rasmussen et al., 2012; Schipanski and Drinkwater 2012). Higher soil $\mathrm{N}$ and $\mathrm{C}$ storage and cycling efficiency under legume-grass mixture was observed compared to legume monoculture (Paustian et al., 1990; Fustec et al., 2010; Rasmussen et al., 2012; Schipanski and Drinkwater 2012; Bell et al., 2012). This was explained by competition for soil $\mathrm{N}$ and also facilitation concerning soil $\mathrm{N}$ uptake between different species for example due to different root systems (Carlsson and Huss-Danell 2003; Schipanski and Drinkwater 2012) and $\mathrm{N}$ transfer between legumes and grasses (Louarn et al., 2014). However, the effect of legume species on soil parameters under grassland associations may depend on the associated grass species (Crème et al., submitted). This may explain the contrasting observations made for physical soil properties such as aggregate stability, i.e. increase under legume species (Angers et al. 1999) and decrease compared to grasses (Peres et al., 2013). This contrasting impact of different legume - grass associations (Table 1) may be explained by species related differences in $\mathrm{N}$ uptake and $\mathrm{N}$ transfer mechanisms (Louarn et al. 2014) as well as differential root activity leading to contrasting microbial activity in the rhizosphere (Sanaullah et al., 2011). In general, introduction of legume species into grasslands may be positive due to their effect on soil fertility, plant growth and stress resistance. However, legume species are more competitive than grass species for example regarding drought resistance (Sanaullah et al., 2012), making the maintenance of equilibrated mixtures a management challenge.

\section{Conclusion}

Although grasslands are in general favourable systems in terms of SOM storage and nutrient cycling, intensification of grassland management may decouple elemental cycles and favour losses of reactive $\mathrm{N}$ and P. Grazing regime and fertilisation influence biogeochemical cycling of carbon and major plant nutrients mainly through their effect on plant activity, which greatly influences rhizosphere processes and nutrient uptake or release. Elemental coupling and decoupling processes controlling SOM storage may occur via plants or microorganisms and controlled by specific fertiliser additions. Further progress is necessary in order to optimise grassland management strategies through species choice, fertilisation, and grazing intensity in order to ensure maximal ecosystem services and productivity of intensively used grassland systems. The vulnerability of the system needs to be reduced especially regarding the expected climate change scenarios. At the current stage of knowledge, we lack information about the impact of physiological plant responses to grassland management on biogeochemical C, N and P cycling in soil. In particular their effects on processes affecting SOM properties and its storage at greater depths are poorly understood. We also crucially need information about the processes controlling the stability of organic N and P forms. Management effects on SOM accumulation and availability of plant nutrients are case dependent and may be strongly related to the pedoclimatic context. More research is needed to disentangle belowground complexity, which may be controllable via management effects on plant activity. 


\section{Acknowledgements}

The authors thank the French ministry of Foreign affaires and the Conicyt for financial support of collaboration between French and Chilean research groups under the framework of the ECOSSUD-CONICYT C13U02 project. P.T. Ngo acknowledges funding under the framework of the project Fondecyt Posdoctorado 3150194. A. Crème was funded by the European community's Seventh Framework programme (FP2012-2015) under grant agreement no. 262060 (ExpeER) and the Regional Council for PoitouCharentes. Moreover, we received funding from the French agency ADEME under the framework of the REACTIFF project AEGES.

\section{References}

Agbenin, J.O., Adeniyi, T. 2005. The microbial biomass properties of a savanna soil under improved grass and legume pastures in northern Nigeria. Agri., Ecosys. Environ., 109, 245-254.

Alexis M.A., Rumpel C., Knicker H., Leifeld J., Rasse D., Péchot N., Bardoux G., Mariotti A. 2010 : Thermal alteration of organic matter during shrubland fire: a field study. Org. Geochem., 41, 690-697.

Allison F.E. 1973. Soil organic matter and its role in crop production. (Elsevier: Amsterdam).

Ammann, C., Flechard, C.R., Leifeld, J., Neftel, A., Fuhrer, J. 2007. The carbon budget of newly established temperate grassland depends on management intensity. Agric. Ecosyst. Environ. 121, 5-20.

Angers, D.A., Edwards, L.M., Sanderson, J.B., Bissonnette, N. 1999. Soil organic matter quality and aggregate stability under eight potato cropping sequences in a fine sandy loam of Prince Edward Island. Can. J. Soil Sci. 79, 411-417.
Bardgett, R.D., Wardle, D.A., Yeates, G.W. 1998 Linking above-ground and below-ground interactions: how plant responses to foliar herbivory influence soil organisms. Soil Bio Biochem. 30, 1867-1878.

Bell, L.W., Sparling, B., Tenuta, M., Entz, M.H. 2012. Soil profile carbon and nutrient stocks under longterm conventional and organic crop and alfalfacrop rotations and re-established grassland. Agric. Ecosyst. Environ., 158, 156-163.

Beniston, J.W., DuPont, S.T., Glover, J.D., Lal, R., Dungait, J.A.J. 2014. Soil organic carbon dynamics 75 years after land-use change in perennial grassland and annual wheat agricultural systems. Biogeochem. 127, 37-49.

Bertrand, I., Chabbert, B., Kurek, B., Recous, S. 2006. Can the biochemical features and histology of wheat residues explain their decomposition in soil? Plant Soil. 281, 291-307.

Bitterlich, W., Kaserer, M., Pottinger, C., Hofer, H.P., Cernusca, A. 1999. Effect of land-use changes on soils along the Eastern Alpine transect. In: Cernusca, A., Tappeiner, U., BayÆeld, N. (Eds.). Land-use Changes in European Mountain Ecosystems. Blackwell Science Ltd, Berlin, Wien, pp. 225-234.

Bol, R., Amelung, W. Friedrich, C., Ostle, N. 2000. Tracing dung-derived carbon in temperate grassland using $13 \mathrm{C}$ natural abundance measurements. Soil Biol. Biochem. 32, 13371343.

Bradford, M.A., Keiser, A.D., Davies, C.A., Mersmann, C.A., Strickland, M.S. 2013. Empirical evidence that soil carbon formation from plant inputs is positively related to microbial growth. Biogeochem. 113, 271-281.

Butterbach-Bahl K., Gundersen P., Ambus P., Augustin J., Beier C., Boeckx P., Dannenmann M., Gimeno B.S., Kiese R., Kitzler B., Ibrom A., Rees R.M., 
Smith K., Stevens C., Vesala, T., ZechmeisterBoltenstern, S. 2011. Nitrogen turnover processes and effects in terrestrial ecosystems. In: The European Nitrogen Assessment. ed. M.A. Sutton, C.M. Howard, J.W. Erisman et al., Cambridge University Press.

Carlsson, G., Huss-Danell K. 2003. Nitrogen fixation in perennial forage legumes in the field. Plant Soil. 253, 353-372.

Celi, L., De Luca, G., Barberis, E. 2003. Effects of interaction of organic and inorganic $\mathrm{P}$ with ferrihydrite and kaolinite-iron oxide systems on iron release. Soil Sci. 168, 479-488.

Cheng W., Kuzyakov Y. 2005. Root effects on soil organic matter decomposition. In: S. Wright, S., Zobel, R. (Eds.), Roots and Soil Management: Interactions Between Roots and the Soil, Agronomy Monograph No. 48, American Society of Agronomy, Crop Science Society of America, Soil Science Society of America. Madison, Wisconsin, USA, pp. 119-143.

Conant, R.T, Paustian, K., Elliott, E.T. 2001. Grassland management and conversion into grassland: effects on soil carbon. Ecol Applic. 11, 343-355.

Conant, R.T. 2010. Challenges and opportunities for carbon sequestration in grassland systems. A technical report. Integrated Cop Management, 9, $1-51$.

Cotrufo, M.F., Wallenstein, M.D., Boot, C., Denef, K., Paul, E. 2013. The microbial efficiency-matrix stabilisation (MEMS) framework integrates plant litter decomposition with soil organic matter stabilization: do labile plant inputs form stable organic matter? Global Change Biol. 19, 988-995.

Crème, A., Rumpel, C., Gastal, F., Chabbi, A. Effect of nitrogen fertilizer replacement by legume on organic matter and phosphorus forms in grassland soil. Plant Soil, submitted.
Crews, T.E., Brookes, P.C. 2014. Changes in soil phosphorus forms through time in perennial versus annual agroecosystems. Agric. Ecosyst. Envrion. 184, 168-181.

Criscuoli, I., Alberti, G., Baronti, S., Favilli, F., Martinez, C., Calzolar, F., Pusceddu, E., Rumpel, C., Viola, R., Miglietta, F. 2014 : Carbon sequestration and fertility after centennial time scale incorporation of charcoal in soils. Plos One. 9,3, e91114.

Crews, T.E., Peoples M.B. 2004. Legume versus fertilizer sources of nitrogen: ecological tradeoffs and human needs. Agric Ecosyst Environ 102, 279-297.

Crews, T.E., Peoples, M.B. 2005. Can the synchrony of nitrogen supply and crop demand be improved in legume and fertilizer-based agroecosystems? A review. Nutr. Cycl. Agroecosyst. 72, 101-120.

Cui, X.Y., Wang, W.F., Niu, H.S., Wu, J., Wang, S.P., Schnug, E. 2005. Effect of long-term grazing son soil organic carbon content in semiarid steppes in Inner Mongolia. Ecol. Res., 20, 519-527.

Dahlin, A.S., Martensson, A.M., 2008. Cutting regime determines allocation of fixed nitrogen in white clover. Biol. Fert. Soils. 45, 199-204.

Daroub, S.H., Ellis, B.G., Robertson, G.P., 2001. Effect of cropping and low-chemical input systems on soil phosphorus fractions. Soil Sci. 166, 281-291.

Dodd, R.J., McDowell, R.W., Condron, L.M. 2014. Manipulation of fertiliser regimes in phosphorus enriched soils can reduce phosphorus loss to leachate through an increase in pasture and microbial biomass production. Agric. Ecosyst. Enrion. 185, 65-76.

Dormaar, J.F., Williams, W.D., 1998. Effect of fortyfour years for grazing on fescue grassland soils. J. Range Manag. 51, 122-126. 
Dungait, A.J., Bol, R., Bull, I.D., Evershed, R.P., 2009. Tracking the fate of dung-derived carbohydrates in a temperate grassland soil using compoundspecific stable isotope analysis. Org. Geochem. 40, 1210-1218.

Dungaith, J.A.J., Cardenas, L.M., Blackwell, M.S.A., Wu, L., Withers, P.J.A., Chadwick, D.R., Bol, R., Murray, P.J., Macdonald, A.J., Whitmore, A.P., Goulding, K.W.T. 2012. Advances in the understanding of nutrient dynamics and management in UK agriculture. Sci. Total Environ. 39-50.

FAOSTAT. 2009. Statistical Database 2007. Rome.

Farrell, M., Hill, PW, Wanniarachchi, S.D., Farrar, J.S., Bardgett, R.D., Jones, D.L. 2011. Rapid peptide metabolism: a major component of soil nitrogen cycling. Global Biogeochem. Cycles. 25, GB3014

Fontaine, S., Mariotti, A., Abbadie, L. 2003. The priming effect of organic matter: a question of microbial competition? Soil Biol. Biochem. 35, 837-843.

Franzluebbers, A.J., Stuedemann, J.A., Schomberg, H.H., Wilkinson, S.R. 2000. Soil organic C and $\mathrm{N}$ pools under long-term pasture management in the Southers Piedmont USA. Soil Biol. Biochem. $32,469-478$.

Franzluebbers, A.J. 2012. The grass roots of carbon sequestration. Carbon Management. 3, 9-11.

Finzi, A.C., Abramoff, R.Z., Spiller, KS, Brzostek, ER, Darby, BA, Kramer, MA, Phillips, RP 2015. Rhizosphere processes are quantitatively important components of terrestrial carbon and nutrient cycles. Global Change Biology, in press.

Fransson, A.M., Jones, D.L. 2007. Phosphatase activity does not limit the microbial use of low molecular weight organic-P substrates in soil. Soil Biol. Biochem. 39, 1213-1217.
Fuentes, B., Dixon, E., Mora, M.L., Turner, B.L., Bol, R. 2012. Dissolved phosphorus composition of grassland leachates following application of dairy-slurry size fractions. J. Plant Nutri. Soil Sci. $175,78-85$.

Fustec, J., Lesuffleur, F., Mahieu, S., Cliquet, J.-B 2010. Nitrogen rhizodeposition of legumes. A review. Agron. Sustain. Dev. 30, 57-66.

Gordon, A.J. 1992. Carbon metabolism in the legume nodule. in Carbon Partitioning Within and Between Organisms. eds Pollock CJ, Farrar JF, Gordon AJ (Bios Scientific Publishers, Oxford, UK), pp 133-162.

Hamilton, E.W., Frank, D.A., Hinchey, P.M., Murray, T.R. 2008. Defoliation induces root exudation and triggers positive rhizospheric feedbacks in a temperate grassland. Soil Biol. Biochem. 40, 2865-2873.

Hamilton, E.W., Frank, D.A. 2001. Can plants stimulate soil microbes and their own nutrient supply? Evidence from a grazing tolerant grass. Ecology. 82, 2397-2402.

Hatch, D.J., Lovell, R.D., Antil, R., Jarvis, S.C., Owen, P.M., 2000. Nitrogen mineralization and microbial activity in permanent pastures amended with nitrogen fertilizer or dung. Biol. Fert. Soils. 30, 288-293.

Henry, F., Vestergård, M., Christensen, S 2008. Evidence for a transient increase of rhizodeposition within one and a half day after a severe defoliation of Plantago arenaria grown in soil. Soil Biol. Biochem. 40, 1264-1267.

Herold, N., Schoning, I. Michalzik, B., Trumbore, S., Schrumpf, M. 2014. Controls on soil carbon storage and turnover in German landscapes. Biogeochem. 119, 435-451.

Haynes, R.J., Williams, P.H. 1993. Nutrient cycling and soil fertility in the grazed pasture ecosystem. Adv. Agron. 49, 119-199. 
Holland, J.N., Cheng, W., Crossley Jr., D.A. 1996. Herbivore-induced changes in plant carbon allocation: assessment of below-ground C fluxes using carbon-14. Oecologia. 107, 87-94

Hill, P.W., Farrar, J., Roberts, P., Farrell, M., Grant, H., Newsham, K.K., Hopkins, D.W., Bardgett, R.D., Jones, D.L. 2011. Vascular plant success in a warming antarctic may be due to efficient nitrogen acquisition. Nature Climate Change 1, $50-53$.

Hooper, D.U., Chapin, III, F.S., Ewel, J. J., Hector, A., Inchausti, P., Lavorel, S., Lawton, J.H., Lodge, D., Loreau, M., Naeem, S., Schmid, B., Setälä, H., Symstad, A.J., Vandermeer, J., Wardle, D.A. 2005. Effects of biodiversity on ecosystem functioning: a consensus of current knowledge. Ecol. Monographs. 75, 3-35.

IPCC (2013) Fifth Assessment Report - WG1.

Jarvie, H.P., Withers, P.J.A., Bowe, M.J., PalmerFelgate, E.J., Harper, D.M., Wasiak, K., 2010. Streamwater phosphorus and nitrogen across a gradient in rural-agricultural land use intensity. Agric. Ecosyst. Environ. 135, 238-52.

Jarvis, S.C., Stockdale, E.A., Shephard, M.A., Powloson, D.S., 1996. Nitrogen mineralisation in temperate agricultural soils: processes and measurement. Adv. Agron. 57, 188-237.

Jiao, N., Herndl, D.A., Benner, R., Kattner, G., Wilhelm, S.W., Kirchman, D.L., Weinbauer, M.G., Luo, T., Chen, F., Azam, F. 2010. Microbial production of recalcitrant dissolved organic matter: long-term carbon storage in the global ocean. Nature Reviews. 8, 593-595.

Jobbagy, E.G., Jackson, R.B. 2000. The vertical distribution of soil organic carbon and its relation to climate and vegetation. Ecol. Appli. 10, 423436.

Johnson, D.W., Hungate, B.A., Dijkstra, P., Hymus, G., Hinkle, C.R., Stiling, P., Drake, B.G.,
2003. The effects of elevated $\mathrm{CO}_{2}$ on nutrient distribution in a fire-adapted scrub oak forest. Ecol. Appli. 13, 1388-1399.

Jouquet, P., Boquel, E., Doan, T.T., Rocoy, M., Orange, D., Rumpel, C., Duc, T.T. 2011. Do compost and vermicopost improve marcornutrient retention and plant growth in degraded tropical soils ? Compost Sci. Utiliz. 19, 15-24.

Kirkby, C.A., Richardson, A.E., Wade, L.J., Passioura, J.B., Batten, G.D., Blanchard, C., Kirkegaard, J.A., 2014. Nutrient availability limits carbon sequestration in arable soils. Soil Biol. Biochem. 68, 402-409.

Klumpp, K., Soussana, JF, Falcimagne, R., 2007. Effects of past and current disturbance on carbon cycling in grassland mesocosms. Agric. Ecosyst. Environ. 121, 59-73.

Klumpp, K., Fontaine, S., Attard, E., Le Roux, X., Gleixner, G., Soussana, J.-F. 2009. Grazing triggers soil carbon loss by altering plant roots and their contol on soil microbial community. J. Ecol. 97, 876-885.

Klumpp, K., Fontaine, S., Attard, E., Gleixner, G., Leroux, X., Soussana, J.F. 2009. How land use change shifts $\mathrm{C}$-poor, productive ecosystems to C-rich unproductive ecosystems and vice versa? J. Ecol. 91, 867-885.

Knicker, H. 2011. Pyrogenic organic matter in soil: Its origin and occurrence, its chemistry and survival in soil environments. Quarter. Internat. 243, 251263.

Kononova, M. 1966. Soil Organic Matter. 2-nd Ed. New York, Pergammon press, 544 p.

Körner, C., Spehn, E.M. 2002. Mountain biodiversity: A global assessment. London: Parthenon.

Kuzyakov, Y., Biryukova, O.V., Kuznetzova, T.V., Molter, K., Kandeler, E., Stahr, K. 2002. Carbon partitioning in plant and soil, carbon dioxide 
fluxes and enzyme activities as affected by cutting ryegrass. Biol. Fert. Soils. 35, 348-358.

Kuzyakov, Y., Gavrichkova, O. 2010. REVIEW: Time lag between photosynthesis and carbon dioxide efflux from soil: a review of mechanisms and controls. Global Change Biol. 16, 3386-3406.

Lal, R. 2004. Soil carbon sequestration impacts on global climate change and food security. Science. 304, 1623-7.

Li, J.H., Yang, Y.J., Li, B.W., Li, W.J., Wang, G., Knops, J.M.H. 2014. Effects of nitrogen and phosphorus fertilization on soil carbon fractions in alpine meadows on the Quinghai-Tibetan plateau. Plosone. 9, 7, e103266.

Lilienfein, J., Wilcke, W., Ayarza, M.A., Vilela, L., do Carmo Lima, X., Zech, W. 2000. Chemical fractionation of phosphorus, sulphur, and molybdenum in Brazilian savannah Oxisols under different land use. Geoderma. 96, 31-46

Lovell, R.D., Jarvis, S.C., 1996. Effect of cattle dung on soil microbial biomass $\mathrm{C}$ and $\mathrm{N}$ in a permanenet pasture soil. Soil Biol. Biochem. 28, 291-299.

Louarn, G., Pereira-Lopès, E., Fustec, J., Gastal, F. 2014. The amounts and dynamics of nitrogen transfer to grasses differ in alfalfa and white clover-based grass-legume mixtures as a result of rooting strategies and rhizodeposit quality. Plant Soil. 1-17.

Merino, C., Matus, F., Nannipieri, P., this issue Rhizosphere priming: effect of nutrient availability, soil enzyme activity and soil.

Macdonald, L.M., Paterson, E., Dawson, L.A.,, Mcdonald, A.J.S. 2004. Short-term effects of defoliation on the soil microbial community associated with two contrasting Lolium perenne cultivars. Soil Biol. Biochem. 36, 489-498.

McLauchlan, K. 2006. The nature and longevity of agricultural impacts on soil carbon and nutrients: a review. Ecosystems. 9, 1364-1382.
McSherry, M.E., Ritchie, M.E. 2013. Effects of grazing on grassland soil carbon: a global review. Global Change Biol. 19, 1347-1357.

McDowell, R.W., Koopmans, G.F. 2006. Assessing the bioavailability of dissolved organic phosphorus in pasture and cultivated soils treated with different rates of nitrogen fertiliser. Soil Biol. Biochem. 38, 61-71.

McDowell R.W., Stewart I. 2005. An improved technique for the determination of organic phosphorus in sediment and soils by $31 \mathrm{P}$ nuclear magnetic resonance spectroscopy. Chemistry Ecology. 21, 11-22.

McDowell, R.W., Dou, Z., Toth, J.D., Cade-Menun, B.J., Kleinman, P.J.A., Soder, K. Saporito, L. 2008. A comparison of phosphorus speciation and potential bioavailability in feed and feces of different dairy herds using IT nuclear magnetic resonance spectroscopy. J. Environ. Qual. 37, 741-752.

McGovern, S.T., Evans, C.D., Dennis,P., Walmsley, C.A., Turner, A., McDonald, M.A. 2014. Increased inorganic nitrogen leaching from a mountain grassland ecosystem following grazing removal: a hangover of past intensive land-use? Biogeochem. 119, 125-138.

Mazzanti, A., Lemaire, G., Gastal, F. 1994. The effect of nitrogen fertilization upon the herbage production of tall fescue swards continuously grazed with sheep. II-herbage consumption. Grass Forage Sci. 49, 352-359

Michuas, D.G., Lauenroth, W.K. 1993. Quantitative effects of grazing on vegetation and soils over a global range of environments. Ecol. Monographes. 63, 327-366.

Miltner, A., Bombach, P., Schmidt-Brücken, B., and Kästner, M. 2012. Som genesis: Microbial biomass as a significant source, Biogeochem. 111, $41-55$. 
Nikolaus, P.A., Kandeler, E., Leadley, P.W., Schmid, B., Tscherko, D., Körner, C. 2001. A link between plant diversity, elevated $\mathrm{CO}_{2}$ and soil nitrate. Oecologia. 127, 540-548.

Nyborg, M., Molina-Ayala, M., Solberg, E.D., Izaurralde, E.C., Malhi, S.S., Janzen, H.H. 1997. Carbon storage in grassland soils as related to $\mathrm{N}$ and $\mathrm{S}$ fertilizers. In R. Lal et al. (ed.) Management of CarbonSequestration in Soil. CRC Press, Boca Raton, FL. pp 421-432.

Nyfeler, D., Huguenin-Elie, O., Suter, M., et al, 2011. Grass-legume mixtures can yield more nitrogen than legume pure stands due to mutual stimulation of nitrogen uptake from symbiotic and nonsymbiotic sources. Agric. Ecosyst. Environ. 140, 155-163.

Oelmann, Y., Richter, A., Rosche, C., Rosenkrzna, S., Temperton, V.M., Weisser, W.W., Wilke, W. 2011. Does plant diversity influence phosphorus cycling in experimental grasslands. Geoderma. 167-168, 178-187.

Paustian, K., Andren, O., Clarholm, M., Hansson, A.C., Johansson, G., Lagerlöf, J., Lindberg, T.,

Pettersson, R., Sohlenius, B. 1990. Carbon and Nitrogen Budgets of Four Agro-Ecosystems With Annual and Perennial Crops, With and Without N Fertilization. J. Appl. Ecol. 27, 60.

Parsons, A.J., thronley, J.H.M., Newton, P.C.D., Rasmussen, S., Rowarth, J.S. 2013. Soil carbon dynamics: The effect of nitrogen input, intake demand and off-take by animals. Sci. Total Environ. 465, 205-215.

Paterson, E., Sim, A. 1999. Rhizodeposition and C-partitioning of Lolium perenne in axenic culture affected by nitrogen supply and defoliation. Plant Soil. 216, 155-164.

Pätzhold, S., Hejcman, M., Barej, J., Schellberg, J. 2013. Soil phosphorus fractions after seven decades of fertilizer application in the Rengen grassland experiment. J. Plant Nutri. Soil Sci. 176, 910-920.

Peres, G., Cluzeau, D., Menasseri, S., Soussanan, J.F., Bessler, H., Engels, C., Habekost, M., Gleixner, G., Weigelt, A., Weisser, W., Scheu, S., Eisenhauer, N. 2013. Mechanisms linking plant community propertis to soil aggregate stability in an experimental grassland plant diversity gradient. Plant Soil. 373, 285-299.

Ramankutty, N., Evan, A.T., Monfreda, C., Foley, J. 2008. Farming the planet: 1. Geographic distribution of global agricultural lands in the year 2000. Global Biogeochem. Cycles 22 GB1003

Rasmussen, J., Søegaard, K., Eriksen, J. 2012. N2fixation and residual effect of four legume species and four companion grass species. Eur. J. Agron.

Rasse, D.P., Rumpel, C., Dignac, M.-F. 2005. Is soil carbon mostly root carbon? Mechanisms for a specific stabilisation. Plant Soil. 269, 341-356.

Redin M., Guénon R., Recous, S., Schmatz, R., Liberalesso de Freitas, L., Aita, C., Giacomini, S.J., 2014. Carbon mineralization in soil of roots from twenty crop species, as affected by their chemical composition and botanical family. Plant Soil. 378, 205-214.

Richardson, A.E., Kirkby, C.A., Banerjee, S., Kirkegaard, J.A. 2014. The inorganic nutrient cost of building soil carbon. Carbon Management. 5, 265-268.

Robinson Kunrath, T., de Berranger, C., Charrier, X., Gastal, F., de Faccio Carvalho, F.C., Lemaire, G., Emile, J.C., Durand J.L. 2015. How much do sodbased rotations reduce nitrate leaching in a cereal cropping system? Agric. Water Management. 150, 46-56.

Rodionov, A., Amelung, W., Peinemann, N., Haumaier, L., Zhang, X., Kleber, M., Glaser, B., Urusevskaya, I., Zech, W. 2010. Black carbon in grassland ecosystems of the world 
Global Biogeochem. Cycles. 24, GB3013, doi:10.1029/2009GB003669.

Rumpel, C. 2008. Does burning of harvesting residues increase the soil carbon storage ? ¿La quema de residuos de cosecha aumenta el almacenaje de carbono en el suelo?. J. Soil Sci Plant Nutri. 8, 44-51.

Rumpel, C., Eusterhues, K., Kögel-Knabner, I. 2010. Non-cellulosic neutral sugar contribution to mineral associated organic matter in top-and subsoil horizons of two acid forest soils. Soil Biol. Biochem. 42, 379-382.

Rumpel, C., Baumann, K., Remusat, L., Dignac, M.F., Barré, P., Deldicque, D., Glasser, G., Lieberwirth, I., Chabbi, A. 2015. Nanoscale evidence of contrasted processes for root-derived organic matter stabilization by mineral interactions depending on soil depth. Soil Biology and Biochemistr. 85, 82-88.

Sanaullah, M., Chabbi, A., Lemaire, G., Charrier, X., Rumpel, C. 2010. How does plant leaf senescence of grassland species influence decomposition kinetics and litter compounds dynamics ? Nutr. Cycl. Agroecosyst. 88, 159-171

Sanaullah, M., Blagodatskaya, E., Chabbi, A., Rumpel, C., Kuzyakov, Y. 2011. Drought effects on microbial biomass and enzyme activities in the rhizosphere of grasses depend on plant community composition. Appl. Soil Ecol. 48, 38-44.

Sanaullah, M., Rumpel, C., Charrier, X., Chabbi, A. 2012. How does drought stress influence the decomposition of plant litter with contrasting quality in a grassland ecosystem? Plant Soil. 352, 277-288.

Schimel, J.P., Jackson, L.E., Firestone, M.K., 1989. Spatial and temporal effects on plant microbial competition for inorganic nitrogen in a California annual grassland. Soil Biol. Biochem. 21, 10591066.
Schipanski, M.E., Drinkwater, L.E. 2012. Nitrogen fixation in annual and perennial legume-grass mixtures across a fertility gradient. Plant Soil, $1-13$.

Schipper, L.A., Dodd, M.B., Pronger, J., Mudge, P.L., Upsdell, M., Moss, R.A. 2012. Decadal changes in soil carbon and nitrogen under a range of irrigation and phosphorus fertilizer treatments. Soil Sci. Soc. Am. J. 77, 246-256.

Senapati, N., Chabbi, A., Gastal, F., Smith, P., Mascher, N., Naisse, C. 2014. Net carbon storage measure in a mowed and grazed temperate sown grassland shows potential for carbon sequestration under grazed system. Carbon Management. 5. 131-144.

Sharpley, A.N., Smith, S.J. 1985. Fractionation of inorganic and organic phosphorus in virgin and cultivated soils. Soil Sci. Soc. Am. J. 49, 1276130.

Sharpley, A.N., Chapra, S.C., Wedepohl, R., Sims, J.T., Daniel, T.C., Reddy, K.R. 1994. Managing agricultural phosphorus for protection of surface waters: issues and options. J. Environ. Qual. 23, 437-451

Shields, J.A., Paul, E.A. 1973. Decomposition of ${ }^{14} \mathrm{C}$ labelled plant material under field conditions. Can. J. Soil Sci. 53, 297-306.

Six, J., Bossuyt, H., Degryze, S., Denef, K. 2004. A history of research on the link between (micro) aggregates, soil biota, and soil organic matter dynamics. Soil Tillage Res. 79, 7-31.

Soussana, J.F., Lemaire, G. 2014. Coupling carbon and nitrogen cycles for environmentally sustainable intensification of grasslands and crop-livestock systems. Agric. Ecosyst. Environ. 190, 9-17.

Steffens, M., Koelbl, A., Totsche, K.U., KögelKnabner, I., 2008. Grazing effects on soil chemical and physical properties in a semiarid steppe of Inner Mongolia (PR China). Geoderma. 143, 63-72. 
Tate, R.L. 1987. Soil Organic Matter Biological and Ecological Effects, Wiley, Chichester, 291 pp.

Turner, B.L., McKelvie, I.D., Haygarth, P.M. 2002. Characterisation of water-extractable soil organic phosphorus by phosphatase hydrolysis. Soil Biol. Biochem. 34, 27-35.

Tsvetkova G.E., Georgiev, G.I. 2007. Changes in phosphate fractions extracted from different organs of phosphorus starved nitrogen fixing pea plants. J. Plant Nutr. 30, 2129-2140.
Whitmore, A.P., Kirk, G.J.D., Rawling, B.G. 2014. Technologies for increasing carbon storage in soil to mitigate climate change. Soil Use Management. in press.

Wilkinson, A., Hill, P.W., Farrar, J.F., Jones, D.L., Bardgett, R.D. 2014. Rapid microbial uptake and mineralization of amino acids and peptides along a grassland productivity gradient. Soil Biol. Biochem. 72, 73-85.

Zeller, V., Kandeler, E., Mair, V. 1997. N-dynamic in mountain grassland with different intensity of cultivation. Aust. J. Agric. Res. 48, 217-230. 